\title{
Time to Turn the Page in Tang and Song History Studies: Exploring the Tang-Song Transformation Theory from Multiple Perspectives
}

\author{
Li Huarui 李華瑞 \\ Professor of School of History, Capital Normal University, \\ Beijing, China \\ lihr2002@163.com
}

\begin{abstract}
In China, Naitō Konan's "theory on modernity since the Song” (Tang-Song transformation theory) did not elicit widespread academic interest until the twenty-first century. The following article provides a comprehensive analysis of the reception to Naitō's theory by Chinese historians and the implications for Chinese Song studies. The author discusses the Naitō hypothesis from six different perspectives: the theoretical basis and political background of Naitō's work, historical development patterns in China and the West, Chinese history as the history of a multiethnic country, international scholarship on the periodization of Chinese history, and the contributions by Chinese scholars. The author concludes that Chinese Tang and Song historians should turn the page and move on from Naitō Konan's modernity theory (transformation theory).
\end{abstract}

\section{Keywords}

China - gender - modernity - Renaissance - Song dynasty - Tang-Song transformation theory

The Japanese scholar Naitō Konan 內藤湖南 [1866-1934] put forward his "Modernity since the Song Dynasty Theory" [Songdai jinshi shuo 宋代近 世說], subsequently referred to as "modernity theory," in the early twentieth century. Following World War II, Naitō's student Miyazaki Ichisada 宮 崎市定 [1901-1995] and others continued to develop his ideas into the more 
commonly used "Tang-Song transformation theory," or "transformation theory."1 Although both theories proved greatly influential with international historians of the Tang [618-907] and Song [960-1279] dynasties for a long time, they initially elicited little response in China. It was not until the early twenty-first century that Naitō's work began to capture the attention of Chinese scholars and became a focus of discussion. Today, as Ge Zhaoguang 葛兆光 referred, "it has become common for Chinese scholars to analyze the Song dynasty on the basis of the modernity or transformation theory." Many Chinese researchers now consider the transformation theory to be self-evident and treat it as a convenient framework that can be applied to a variety of historical contexts. This approach has given rise to a whole series of new "transformation theories," such as the "mid-Tang transformation theory," the "Northern-Southern Song transformation theory," and the "Song-Yuan transformation theory." Over the past twenty years, Chinese scholars have tried to improve the standard of research on Tang and Song studies by breaking down the dynastic periodization between the two historical periods. If we examine the results of these efforts, however, it becomes clear that the effects of the transformation theory have been minimal, with the theory's shortcomings outweighing its benefits. The transformation theory has fulfilled its historic mission; it is time for Tang and Song historians to turn the page. The following article substantiates this proposition by discussing Naitō's modernity theory from six different perspectives.

\section{The History of the Transformation Theory}

To clarify the starting point of the academic discussion, we outline important aspects of the theoretical foundations of the Naito hypothesis and the origins of its status as a paradigm in Song history.

\subsection{Evolution of the Concept of "Modernity"}

The first iteration of Naitō's views was the theory on modernity since the Song dynasty. The Chinese term for modernity, jinshi 近世, is found in records predating the Qin dynasty [221-206 ВСE] but began to appear more frequently in

1 Professor Naitō is best known under his literary name Naitō Konan 內藤湖南 but is sometimes also referred to by his legal name, Naitō Torajiro 內藤虎次郎. In English-language literature, Naitō Konan's theory is often called the "Naitō hypothesis."

2 Zhejiang daxue Songxue yanjiu zhongxin 浙江大學宋學研究中心, ed., Songxue yanjiu jikan 宋學研究集刊 [Edited Volume of Research in Song Studies] (Hangzhou: Zhejiang daxue chubanshe, 2008), 1.3. 
records originating after the Qin and Han dynasties [206 BCE-220 CE]. As a temporal marker and a concept for periodization, jinshi always takes the "present" as its point of reference. Because the present is continuously displaced, the concept of jinshi also remains fluid, only vaguely pointing to an undefined period that is relatively close to the present.

After 1840, Western learning spread eastward, making it unavoidable that Western methods of historical periodization would also influence the interpretation of Chinese history. In 1917, Fu Sinian 傅斯年 [1896-1950] stated: “There is a consensus that there are three stages in Western history, namely, antiquity [shangshi 上世], the Middle Ages [zhongshi 中世], and modernity [jinshi].” Chinese historians introduced the Western model of periodization to China during the late Qing dynasty [1616-1911] and the early Republican period [19121949], and Japanese scholars employed this model to divide Chinese history into different periods. However, they had not yet begun to analyze Chinese history from the perspective of the Western path of development. The first real attempt to identify major trends in China's historical development using the idea of "world history" - a model that revolves around our knowledge of the development of Western civilization - was the modernity theory by Naitō, who was the main representative of the Japanese Kyoto school of Chinese history. Between 1910 and 1920, Naitō developed the hypothesis that the Song dynasty marked the beginning of Chinese modernity. He published a series of works, including A Treatise on China [Shina ron 支那論], Modern Chinese History [Shina kinseishi 支那近世史], and “A General View of the Tang and the Song." ${ }^{4}$ Naitō argued that the major transformation from Chinese antiquity to modernity occurred between the Tang and the Song dynasties.

\subsection{The Theoretical Basis of Naitō Konan's Modernity Theory}

Naitō Konan's modernity theory has two main threads. First, Naitō was clearly influenced by François Guizot's book Histoire Générale de la Civilisation en Europe, which presents Western feudalism as a form of aristocracy. ${ }^{5}$ By substituting Western feudalism with China's aristocratic system, Naitō could draw parallels between China and the Western development pattern from feudal society to a monarchy as described by Guizot. In his book Treatise on China,

3 Fu Sinian 傅斯年, Shixue fangfa daolun: Fu Sinian shixue wenji 史學方法導論: 傅斯年 史學文輯 [Introduction to Historical Methods: Collected Works on Historical Research by Fu Sinian] (Beijing: Zhongguo renmin daxue chubanshe, 2004), 52-53.

4 Naitō Konan 內藤湖南, “Gaikatsuteki Tō Sō jidai kan 概括的唐宋時代觀 [General View of the Tang and the Song]," Rekishi to chiri 歷史と地理 9, no. 5 (1922).

5 François Guizot, Histoire Générale de la Civilisation en Europe depuis la Chute de L'Empire Romain jusqu’à La Révolution Française (Brussels: N. J. Gregoir, V. Wouters et Cie, 1840). 
published in 1914, Naitō described China's development from an aristocracy to a system of monarchical despotism and eventually to a republican system of government as part of a fundamental pattern in Chinese history. As in the views expressed by Guizot, Naitō believed that a monarchical system of government causes polarization between the state (the sovereign) and the common people and eventually leads to unrest and revolution. Naitō, Uchida Ginzō 內田銀藏 [1872-1919], and other cultural historians in the Kyoto school held viewpoints on history that were formed by Guizot's Histoire and Fukuzawa Yukichi's 福澤諭吉 [1835-1901] Outline of Civilization Theory and based on ideas about Western feudalism and absolute monarchy. ${ }^{6}$

Second, Naitō's theory was clearly influenced by the historical patterns and characteristics of the Renaissance in Europe. Naitō began to draw analogies between China's Song dynasty and the Western Renaissance-a proposition that was eventually developed more comprehensively by his student Miyazaki Ichisada. Miyazaki concluded that "the eastern renaissance (the Song dynasty) occurred three centuries prior to the Western Renaissance," with the Eastern renaissance "inspiring and influencing" developments in the West. ${ }^{7}$ Using a linear concept of history and following the European pattern of renaissance, religious reform, and enlightenment, Miyazaki searched for a comparable timeline in Eastern history_an East Asian "modernity" that predated the European one. Naitō Konan and Miyazaki Ichisada's modernity theory (transformation theory) created a new narrative in East Asian history, attempting to surpass the European model of historical development. They believed that, after the commencement of the Song dynasty, China had successfully come through its middle ages (Han through Tang dynasties). During the Song period, they argued, China experienced a renaissance (with a flourishing culture), religious reform (with neo-Confucianism replacing Buddhism as the main belief system), and the rise of an urban population (due to a developed system of commerce) as well as the idea of the nation-state (because its aristocracy was in decline and it had an increasingly powerful sovereign). Over the past hundred years, the concept of renaissance has been widely researched and discussed in Japan as well as in China.

Naitō Konan not only relied on Western research methods and viewpoints for his modernity theory but also compared the historical conditions that gave

6 Fukuzawa Yukichi 福澤諭吉, Bunmeiron no gairyaku 文明論之概略 [Outline of Civilization Theory] (Tokyo: Iwanami Shoten, 1931).

7 Miyazaki Ichisada 宮崎市定, “Dongyang de jinshi 東洋的近世 [East Asia's Early Modern Age]," in Riben xuezhe yanjiu Zhongguo shi lunzhu xuanyi 日本學者研究中國史論著選譯 [Translations of Selected Works by Japanese Scholars on Chinese History], ed. Liu Junwen 劉俊 文 and trans. Huang Yuese 黃約瑟 (Beijing: Zhonghua shuju, 1992), 1.236-37. 
rise to the modern nation-states in Europe and in Meiji Japan-namely, sovereigns joining hands with the common people to bring down the power of the aristocracy, thereby creating a system of centralized power. It is important to note, however, that Naitō's ideas were not entirely identical to the transformation theory that his successors developed after World War II. To be precise, Naitō's own "modernity" was China's Qing dynasty. He believed that certain patterns in Qing society, politics, economics, and culture had already begun to take shape during the Song dynasty, especially the system of monarchical despotism. Naitō had deep knowledge of famous Chinese historians and thinkers since the seventeenth century, including Gu Yanwu 顧炎武 [1613-1682], Huang Zongxi 黃宗羲 [1610-1695], Dai Zhen 戴震 [1724-1777], and Zhang Xuecheng 章學誠 [1738-1801]. He was greatly influenced by Gu Yanwu and Huang Zongxi's critique of the system of monarchical despotism but frequently relied on their work in a way that was contrary to their original intentions. ${ }^{8}$ Although $\mathrm{Gu}$ Yanwu and Huang Zongxi's critique of the monarchical despotism of the Song and Ming [1368-1644] dynasties was fueled by their desire to return to the feudal system of China's antiquity, Naitō, by contrast, studied the "progressive nature" of the rise of monarchical despotism through his analysis of the societal and cultural changes during the Song. Despite his reliance on Western research methods and viewpoints, Naitō Konan did not simply echo the West.

\subsection{Naitō Konan's Successors and the Transition from the Modernity Theory to the Transformation Theory}

Naitō Konan's hypothesis that the Song dynasty marked the beginning of Chinese modernity was based mostly on his observations about Chinese society and culture. Miyazaki Ichisada strengthened Naitō's position by contributing further research on China's economy and institutions, eventually turning the Naitō hypothesis into one of the major propositions of the Kyoto school. Whereas the arguments supporting Naitō's theories were based on his observations of China's historical development, Miyazaki Ichisada instead chose to approach the question from the perspective of world history. He argued that China's new Song culture was not only a Chinese but also an "East Asia's Early Modern Age" [dongyang de jinshi 東洋的近世]. ${ }^{9}$

8 Joshua Fogel 傅佛果, Neiteng Hunan: Zhengzhi yu hanxue (1866-1934) 內藤湖南: 政治與 漢學 (1866-1934) [Politics and Sinology: The Case of Naitō Konan (1866-1934)], trans. Tao Demin 陶德民 and He Yingying 何英鶯 (Nanjing: Jiangsu renmin chubanshe, 2016), 203, 194.

9 Ren Seikichi 連清吉, “Neiteng Hunan yu Gongqi Shiding: Riben Jingdu Zhongguo xuezhe de shiguan 內藤湖南與宮崎市定——日本京都中國學者的史觀 [Naitō Konan and Miyazaki Ichisada: The Historical Viewpoint of the Sinologists of Japan's Tokyo School]," in Chang Bide jiaoshou bazhi jinwu shouqing lunwenji 昌彼得教授八秩晉五壽慶論文集 
In his explanation of the societal differences between the Tang and Song dynasties, Naitō did not rely on direct analogies between China's middle ages and modernity and the Western transformation from feudalism to modern capitalism. Miyazaki Ichisada, however, made use of such analogies, for instance, in suggesting the concept of a "nationalism of East Asian modernity" [dongyang jinshi de guomin zhuyi 東洋近世的國民主義]. Miyazaki believed that, from the perspective of world history, the East and the West shared certain structural patterns and followed similar trajectories in their historical development. He rejected the idea of a Western-centric approach to history, paving the way for future research on regions on the periphery. Miyazaki attached great importance to the intrinsic development of modern East Asian societies, seeing them as a major cause for Japanese modernization. The importance of Chinese cultural resources, especially during the period of Tang-Song transformation, became a central topic in scholarship on East Asian history. ${ }^{10}$ As a consequence, the focus of the modernity theory shifted from the origins of Qing political culture to the historical "progress" that resulted from societal transformations during the Tang and Song. This is how the "modernity theory" developed into the "transformation theory."

The transformation theory has several theoretical weaknesses and does not entirely conform to China's historical circumstances. The historical institute at the University of Wuhan has aptly summarized these concerns as follows. First, the transformation theory is not appropriate for China's national conditions and has already been negated by the anti-imperialist and anti-feudal political struggle in modern China. Second, the concepts of an "era of aristocracy" and "monarchical despotism" are exceedingly vague. Third, the theory lacks an objective and clear definition of what constitutes modernity. Fourth, the transformation theory only describes a historical phenomenon, without providing any explanation of the driving forces behind these developments. Fifth, transformation theory takes the whole of China as its object of study without giving credit to the complexity and regional nature of Chinese history. Sixth, a theoretical analysis of the pre-Qin and pre-Han periods, including the Xia [с. 2070-16оо вСе], Shang [16оо-1046 в ве], and Zhou [1046-256 вСе]

[Festschrift for Professor Chang Bide's Eigthy-Fifth Birthday], ed., Tamkang daxue zhongwenxi 淡江大學中文系 and Yu xian suo 語獻所 (Taipei: Taiwan xuesheng shuju, 2005), 325-44.

10 Xiong Wei 熊偉, “Tang-Song biange lun tixi de yanhua 唐宋變革論體系的演化 [The Evolution of the System of the Tang-Song Transformation Theory]," Dianzi keji daxue xuebao 電子科技大學學報 [Journal of the University of Electronic Science and Technology of China], no. 5 (2008). 
dynasties, is lacking. The basis for the transformation theory is rather weak for these six reasons.

Naitō's theory not only was the result of his academic concern about the historical periodization of Chinese history but also was influenced by his interest in China's political developments, as well as Japan's China policy throughout his lifetime. After World War II, modernity theory-developed and enriched by Naitô's students and the Kyoto school—-was concerned primarily with questions regarding the periodization of Chinese history and the nature of Chinese society. However, irrefutable evidence indicates that modernity theory as originally proposed by Naitō Konan was deeply intertwined with Japanese militarism. Joshua Fogel's book Politics and Sinology: The Case of Naitō Konan (1866-1934) makes four points that are especially noteworthy with regard to this question.

First, Naitō Konan was a supporter of Japan's militarist policy of aggression against China. In the months after the outbreak of the First Sino-Japanese War [1894-1895], Naitō wrote four articles praising the victorious Japanese military. In these articles, he made the following argument: "While it is indisputable that Japan has a mission in China, this mission must ultimately be based on China's long-term historical and cultural developments."11

Second, Naitō Konan was a political commentator first and a sinologist with a focus on Chinese history second. His academic scholarship clearly served his political opinions. In his studies on Chinese culture, Naitō was deeply influenced by scholars such as Gu Yanwu, Huang Zongxi, Qian Daxi 錢大听 [1728-1804], Dai Zhen, and Zhang Xuecheng, and he internalized their spirit of combining theoretical studies with the practical application of knowledge.

Naitō firmly believed that solving real world problems ought to be an important goal of academic research. He was therefore opposed to the idea of leaving career politicians and militarists to determine Japan's Asia policy. Based on his unique and traditional understanding of Chinese culture and history, Naitō continued to comment on contemporary political questions such as China's reform and modernization as well as Japan's role in these developments. ${ }^{12}$

\footnotetext{
11 Fogel, Neiteng Hunan, 82-83.

12 Fogel, Neiteng Hunan, 11.
} 
Naitō's Treatise on China was not written as a comprehensive discussion of Chinese history but, rather, was meant to address the practical question of how to respond to China's state of chaos following the Xinhai Revolution $[1911-1912] .^{13}$

Third, Naitō Konan was known as an outstanding China scholar who showed both respect and appreciation for Chinese culture. But his cultural appreciation always remained secondary to his overall goal of benefitting the Japanese nation. Naitō's research on Chinese history and culture was based on his desire to "understand the origins of Japanese culture" and shed light on its future fate. ${ }^{14}$ During the First Sino-Japanese War, Naitō published three editorials in which he used a cultural approach to explain his theory of a Japanese "mission" in China [tianzhi lun 天職論]. Fogel pointed out that Naitō's theory of a Japanese mission was based on the following understanding:

In the China-centric East Asian cultural sphere of influence, China and Japan shared a common sinological tradition. Based on this understanding of China, Naitō ceased, to a certain extent, to understand China as a nation-state, instead seeing it merely as the origin of Chinese "culture" and "civilization." Naitō therefore concluded that in order to protect Chinese "culture" and "civilization," Japan had to protect and even dominate China. ${ }^{15}$

Fourth, Naitō developed a theory to explain the phenomenon of shifting cultural centers. Naitō believed that, after the Meiji Restoration [1868], Japan had come to represent the culture of the East and gained sufficient strength to contend with Western culture. He was convinced that Japan would replace China as the cultural center of the East. Chinese culture would eventually be melted away by Japan's unique cultural characteristics to form the "new height" of Eastern civilization. This, Naitō argued, was Japan's cultural “mission" for the future. ${ }^{16}$ The reason for Naitō's misconception about Chinese culture was his modernity theory. Naitō was persuaded that China had entered modernity with the Song dynasty, roughly eight hundred to a thousand years before his time. With this development, China had preceded the world's progress toward modernity by four to five centuries. It was precisely this premature development, Naitō

\footnotetext{
13 Fogel, Neiteng Hunan, 194.

14 Qian Wanyue 錢婉約, Neiteng Hunan yanjiu 內藤湖南研究 [Research on Naitō Konan] (Beijing: Zhonghua shuju, 2004), 135.

15 Fogel, Neiteng Hunan, 86.

16 Yang Yongliang 楊永亮, “Neiteng Hunan 'Songdai jinshi shuo' wenhua tanze 內藤湖南‘ 宋代近世說”文化探賾 [Exploring the Cultural Subtleties of Naitō Konan's 'Modernity Theory']" (PhD diss., Northeast Normal University, 2015), 1.
} 
argued, that eventually led to China's difficulties in administration and governance during the Qing dynasty. The modern system of monarchical despotism had alienated royal officials from government affairs and eventually curbed China's progress toward a civilized society. Naitō believed that an external "stimulus" could have remedied this situation, an idea similar to the "impact and response model" used to analyze modern Chinese history. ${ }^{17}$ Despite his respect for Chinese culture, Naitō approached his research from the perspective of safeguarding Japanese national interests. We therefore cannot ignore the fact that his modernity theory provided theoretical support for Japan's "compassionate" invasion of China.

\section{The Transformation Theory from the Perspective of Gender}

Naitō Konan's hypothesis on the Song dynasty as the beginning of Chinese modernity and Miyazaki Ichisada's transformation theory-the attempt to explain Naitō's hypothesis by drawing on the European path to modernityhave one important point in common: they fail to touch upon questions concerning women. The reason is presumably that all the historians concerned were themselves male. Naitō and Miyazaki drew analogies between Song culture and the European Renaissance, declaring culture the most obvious marker of a society's entrance into modernity. They saw the Renaissance "as an age of reflection on the history of mankind" and a period that was "self-conscious about the Middle Ages, rediscovering antiquity, and at the same time creating modernity."18 Our understanding of the question of whether the Song dynasty was indeed the beginning of Chinese modernity would benefit by our use of a gender perspective to analyze the changing status of Chinese women between the Song dynasty and the early twentieth century and compare it to the status of women in Western societies from the time of the Renaissance until the twentieth century.

Research over the past twenty to thirty years has shown that the ordinary living conditions of women during the Renaissance were complicated and multifaceted. Women were still subject to suppression and restrictions by the patriarchal system and far from "enjoying equal status to men."19 But many women dared to challenge the status quo, a phenomenon that has been called

\footnotetext{
17 Yang Yongliang, "Neiteng Hunan," 1.

18 Miyazaki Ichisada, "Dongyang de jinshi," 236.

19 Liu Yaochun 劉耀春, “Wenyi fuxing shiqi funü shi yanjiu 文讛復興時期婦女史研究 [Research on the History of Women during the Renaissance]," Lishi yanjiu 歷史研究, no. 4 (2005): 182.
} 
"Renaissance feminism."20 In fact, the position of women in society began to improve gradually beginning in the Renaissance. In the fifteenth century, women in Europe not only participated broadly in the economy but also began to extensively engage in politics. Although women in sixteenth-century England did not have direct voting rights, they were able to express their political will by choosing deputies to take part in elections on their behalf.

Women in high society had already begun to wield political power, with some rights being legally inherited and others "seized" intentionally. Throughout European history, whether in ancient Greece or ancient Rome or during the Middle Ages, the assumption of the role of an emperor, a king, or a similar position of power had always been the exclusive privilege of men. Beginning in the fourteenth century, however, a series of female monarchs appeared, with their number eventually exceeding thirty. Sharon Janson, an expert on women's history, stresses the factor of gender in her research and analyzes the political history of early modern Europe from the perspective of female rulers. ${ }^{21}$

Even though European women only gained the right to vote after World War I, they were able to continuously improve their position in society from the Renaissance onward through their struggle with the patriarchal system. Eventually, the rulers in these patriarchal systems reduced their prejudice toward and control over women. Throughout this struggle, the position of women in society gradually improved in keeping with the ongoing progress of modern societies. The status of Chinese women, in comparison, followed a vastly different trajectory after the Song dynasty.

Our knowledge about the conditions for women during the Song dynasty has developed in stages. After the 199os, some scholars asserted categorically that the status of women had slightly improved during the Song, providing them with a freer social environment than either before or after the Song dynasty. Most objective research, however, still concludes that the position of women actually worsened during the Song compared to the Tang dynasty. In this regard, the following three points should be noted.

First, at the end of the Tang dynasty and during the Five Dynasties and Ten Kingdoms period [907-979], Chinese society was in disarray, with the traditional clan system disintegrating. In the wake of the movement to revitalize Confucianism [ruxuefuxing yundong 儒學復興運動], a discussion surrounding

$20 \quad$ Liu Yaochun, "Wenyi fuxing shiqi," 184.

21 See Hou Jianxin 侯建新, “Xifang funü shi yanjiu shuping 西方婦女史研究述評 [Review of Western Research in Women's History]," Tianjin shifan daxue xuebao 天津師範大學 學報, no. 5 (1991); Liu Yaochun, “Wenyi fuxing shiqi funü shi yanjiu”; Wang Suping 王素 平, "Xifang xuejie guanyu jindai zaoqi Yingguo funü shi de yanjiu 西方學界關於近代 早期英國婦女史的研究 [Western Academic Research on the Early Modern History of British Women]," Jingji shehui shi pinglun 經濟社會史評論, no. 3 (2010). 
the proper status of women in society strengthened the Confucian yin-yang theory [yin-yang xueshuo 陰陽學說] from the beginning of the Song until the reign of the Song emperor Renzong 仁宗 [r. 1022-1063]. At the same time, the resurgence of ancestor veneration caused a revival of the Chinese kinship system [zongfa zhi 宗法制], which had been all but destroyed. The reconstruction and development of the patriarchal clan system [jiazu zhidu 家族制度] directly affected the position of women, and Confucian ethics were increasingly integrated into family and clan regulations. This shows that the Song dynasty placed great emphasis on preventing illegitimate relations between the sexes and on segregation between men and women in society. More vigilance against women gaining political influence occurred during the Song dynasty than any other period.

Second, although China's imperial examination system [keju zhidu 科舉制 度] originated during the Sui [581-618] and Tang dynasties, only during the Song dynasty did the system become accessible to the common Chinese people. Anyone had the right to take part in the examinations, whether government officials or the common people. It was also during the Song period that the selection process for candidates changed from a system of recommendations to a system based on personal talent and ability. If we examine the civil service examination system from the perspective of gender, it becomes obvious that women, who comprised around half the population, were entirely excluded. Women were denied the right to take part in the examinations and become public officials as well as the right to education and personal development more generally. In essence, the civil service examination system embodied the gender hierarchy of the Song dynasty and exacerbated discrimination against women during this period.

Third, the transition from the Tang to the Song dynasty was an age of major societal changes in China after the Spring and Autumn [770-476 вСE] and the Warring States [475-221 BCE] periods. The hierarchies and structures of these societies, built around the distinction between public officials and ordinary men, strictly excluded women. Under the premise of differential treatment and given sufficient personal talent and opportunity, almost all men-with the exception of members of the lowest social strata or members of a number of base professions - had the chance to improve their social status and rank in society. Women, by contrast, had no opportunity to improve their social rank independently. Because of their subordinate status, women could change their rank in society only in connection with the rank of a man. ${ }^{22}$

22 See Yang Guo 楊果, “Xingbie shijiao xia de Songdai lishi 性別視角下的宋代歷史 [Song History from the Perspective of Gender]," Huaxia wenhua luntan 華夏文化論壇, no. 2 (2015). 
In addition, the phenomenon of foot-binding, which first appeared in the Southern Tang [937-975] during the Five Dynasties and Ten Kingdoms period, now plays an important role in research on women's history in China. The number of women with bound feet was already comparatively large during the late Northern Song [960-1127] and the early Southern Song [1127-1279] periods. By the mid-Southern Song, at the latest during the reign of emperor Ning Zong 寧宗 [r. 1194-1224], the practice of foot-binding had turned from a fashion phenomenon into a local custom. During the final years of the Yuan dynasty [1206-1368], the practice began to develop into a general custom, a process that was completed only in the Ming period. After the establishment of the Yuan dynasty, the important Cheng-Zhu school of neo-Confucianism [Cheng-Zhu lixue 程朱理學] continued to inform public ideology. Ideals of female chastity grew more influential, and the desire to use foot-binding as a way to gain control over women became more pronounced. During the Ming dynasty, footbinding was more widespread than it had been during the Song and further reduced opportunities for interaction between men and women. Whereas the original custom of foot-binding was driven mostly by aesthetics, it gradually developed into a general custom designed to prevent illicit relations between the sexes. Eventually, bound feet became a comically distorted female characteristic, before women were eventually reduced to objects enslaved by men.

The fate of women and their declining social status after the Song dynasty show that Chinese history was not on the same trajectory as history in the West, where the Renaissance was followed by the industrial revolution and modernity.

\section{Transformation Theory from the Perspective} of a Multiethnic Country

China has been multiethnic since antiquity. If we examine the modernity theory from this perspective, it becomes clear that Naitō Konan's idea of "China" was limited to areas under political control by the Han Chinese, the "natives of China." Naitō viewed the Jin [1115-1234], Yuan, and Qing dynasties as political rule as a result of alien conquest. After World War II, Miyazaki Ichisada, Saeki Tomi 佐伯富 [1910-2006], and others made substantial additions to our understanding of the characteristics of China's societal and economic developments during the Song. Even though Miyazaki and Naitō's methods of argumentation were not the same, they eventually arrived at similar conclusions. Both agreed that China's social development stagnated for more than a thousand years between the Song and the late Qing dynasty. As a result, European and North 
American scholars generally understood modernity theory as the proposition that China had failed to develop a modern society after the Song. Under the influence of the Naitō hypothesis, most scholars believed that China's society had stagnated after a period of rapid development during the Song and that this state of affairs resulted because China was "increasingly isolating itself from the outside world and restricting external trade under Yuan and especially under Ming rule." 23

Japanese historians also began to pay attention to these questions. Based on the theory of a Tang-Song transformation, the successors to Naitō Konan's modernity theory naturally explored the question of continuity between the Song and Yuan dynasties. Especially important in this regard was the question of how modernity theory was related to the idea of a Ming-Qing transition period, an additional Japanese theory on the periodization of Chinese history. Edited by Japanese scholars and published in 1996, the book Basic Questions of Historical Studies on the Song and Yuan Dynasties represented the views of Japanese historians on modernity theory between the 197os and the 199os. ${ }^{24}$

If we understand the Tang-Song transformation as an isolated event, accept that China's development into a modern society was interrupted after the Northern Song, and agree that Chinese society once again experienced massive changes during the mid-Ming, how do we then explain the period of stagnation between the Yuan and the mid-Ming dynasty? How can we understand the transition and the connection between the Tang-Song transformation and the transformation that occurred during the second half of the Ming dynasty? All these became important questions for European, North American, and Japanese scholars working on Chinese history from the Southern Song onward. In 1997, an international conference in California called "The Song-Yuan-Ming Transition: A Turning Point in Chinese History?" focused on the long-term societal changes since the late Tang. Discussions ranged from the historical importance of the "Song-Yuan-Ming transition" to the relationship between state and society during this period.

23 Paul Smith 史樂民, “Song-Yuan-Ming de guodu wenti 宋、元、明的過渡問題 [The Question of the Song-Yuan-Ming Transition]," in Dangdai xifang hanxue yanjiu jicui: Zhonggushi juan 當代西方漢學研究集萃——中古史卷 [Selection of Research by Contemporary Western Sinologists: Ancient Chinese History], ed. Patricia Buckley Ebrey et al. and trans. Zhang Yi 張禕 et al. (Shanghai: Shanghai guji chubanshe, 2012), 251.

24 Sugiyama Masaaki 杉山正明, “Menggu shidai shi yanjiu de xianzhuang ji keti 蒙古時 代史研究的現狀及課題 [Current State and Questions in Historical Research on the Mongol Period]," Song-Yuan shixue de jiben wenti 宋元史學的基本問題 [Basic Questions of Song and Yuan History Studies], ed. Kondo Kazunari 近藤一成 (Beijing: Zhonghua shuju, 2010). 
Paul Smith has summarized the research on this topic as follows: "The establishment of the Song dynasty is the beginning of the Song-Yuan-Ming transition." He wrote:

If we view the Song-Yuan-Ming transition from a regional perspective, Jiangnan stands out as the sole region of China spared from war and destruction of the time. This makes it useful to think of the Song-Yuan-Ming transition as the localization to Jiangnan of the most important social, economic, and cultural trends of the Tang-Song transformation. Jiangnan's unique status in the transitional era can be seen in the two areas most susceptible to the destruction caused by wars: population trends and cycles of regional development. ${ }^{25}$

In "Current State and Questions in Historical Research on the Mongol Period," the Japanese scholar Sugiyama Masaaki 杉山正明 argued that:

In order to fully understand China's Ming period, we need to actively engage in research on the Jiangnan region during the Southern Song and the Yuan dynasty. From a Eurasian perspective, the Mongol empire absorbed the heritage of the Southern Song, turning Jiangnan into the world's first wealthy "society of production" (after thorough comparison with other regions at the time) that was open to the world both by land and by sea. If we compare the Mongol period to similar time periods in Eurasia and Africa, the superiority of the Jiangnan society becomes obvious. ${ }^{26}$

Although Japanese scholars seem to hold viewpoints that are largely similar to those of their European and North American colleagues, it is important

25 Paul Smith 史樂民, “Song-Yuan-Ming de guodu wenti 宋、元、明的過渡問題 [The Question of the Song-Yuan-Ming Transition]," in Dangdai xifang hanxue yanjiu jicui: Zhonggushi juan 當代西方漢學研究集萃——中古史卷 [Selection of Research by Contemporary Western Sinologists: Ancient Chinese History], ed. Patricia Buckley Ebrey et al. and trans. Zhang Yi 張禕 et al. (Shanghai: Shanghai guji chubanshe, 2012), 252, 254. Jiangnan 江南 refers to regions south of the lower Yangtze River and around its delta.

26 Sugiyama Masaaki 杉山正明, “Menggu shidai shi yanjiu de xianzhuang ji keti 蒙古時 代史研究的現狀及課題 [Current State and Questions in Historical Research on the Mongol Period]," in Song-Yuan shixue de jiben wenti, 287-88. 
to point out that fundamental differences continue to exist. The idea of a Song-Yuan-Ming transition, for instance, does not support the extension of the modernity theory to later time periods. This type of research reduces China's pluralistic historical development to the Jiangnan region-a typical example of researchers imposing their subjective viewpoints onto China's rich and varied history. of International Song Studies

Naitō Konan's modernity theory had an enormous effect on the work of international sinologists in the twentieth century. But during the second half of the twentieth century and especially after Western-centric approaches to history were critiqued and eventually revised, most international sinologists have essentially renounced Naitō's European-style modernity theory.

\section{1}

The Development of the Transformation Theory in Japanese Scholarship

Evaluating the benefits and drawbacks of Western methods of periodization in the late 1970s, Japanese scholars began to see the idea of "modernity" - as used by Western historians and social scientists - as a construct based on the development of European societies. The Western systems of slavery and feudalism in particular proved difficult to apply to China. Research on China's premodern "sprouts of capitalism" was equally insufficient for showing that China would have developed into a capitalist society on its own.

Kishimoto Mio 岸本美緒, a well-known historian of the Ming and Qing dynasties, realized that, beginning in the late nineteenth century, China and Japan began to use the two terms for modernity jindai 近代 (kindai in Japanese) and jinshi (kinsei in Japanese) differently. Kishimoto argued that, unlike jinshi, jindai carried a connotation of Western influence. Eventually, jindai replaced jinshi in China. Beginning in the 1930s, the idea of the Opium Wars [1840-1842] as the beginning of Chinese modernity [jindai] began to gain in popularity. For Chinese scholars, the invasion by foreign imperialists and the destabilization of traditional Chinese systems of governance were the real symbols of modernity. The controversy in the 195os and 196os about Chinese modernity [jinshi] 
between two schools of Japanese historians - the Rekiken school ${ }^{27}$ and the Kyoto school — was mostly a conflict about these two terms for modernity. ${ }^{28}$

Japanese scholars eventually worked out a new explanation for the nature of modernity [jinshi] in Chinese and East Asian history, suggesting that the formation of "traditional society" [chuantong shehui 傳統社會] was equivalent to the process of "modernization" [jinshihua 近世化]. This interpretation of modernity was part of the knowledge system that was representative of Japanese scholarship beginning in the mid-199os. The Tang-Song transformation was considered a major change in the theory on the starting point of China's creation of a "traditional society." 29 The concept of "traditional society" used here is obviously not identical to Miyazaki's idea of a European-style "modern society." This shows that European modernity theory has been called into question and reinterpreted from various angles.

\subsection{The Development of the Transformation Theory in Europe and North America}

The effect of Naitō Konan and Miyazaki Ichisada's theories on European and North American scholarship was somewhat complicated. Western academics approved of Naitō's viewpoint that the political, economic, cultural, and military characteristics of the Qing had originated in the Song dynasty, especially Naitō's idea of the Tang-Song transition as an important point in the periodization of Chinese history. At the same time, many acknowledged Miyazaki Ichisada's great achievements in Song social economics and culture.

27 Rekiken 歴研 is the abbreviation for a Japanese group of historians called Rekishigaku kenkyukai 歴史學研究會 [Historical Science Society of Japan] founded in Tokyo in the 193os. The group was left leaning and pursued historical studies based on a Marxist understanding of historical development. In the Chinese-language version of this article, the author refers to this group of historians as liyan pai 歴研派 [Historical Research School].- Trans.

28 Kishimoto Mio 岸本美緒, “Congxin sikao Zhongguo 'jinshi' shi 從新思考中國(近世, 史 [Rethinking 'Modernity' in Chinese History]," in Lishi fenluntan lunwen huo zhaiyao ji 歷史分論壇論文或摘要集 [Collection of Conference Papers and Abstracts of the Forum on History], from the Beijing Luntan (2005) Wenming de hexie yu gongtong fanrong 北 京論壇 (2005) 文明的和諧與共同繁榮 [Beijing Forum 2005: The Harmony of Civilizations and Prosperity for All] (Beijing: Beijing luntan zuzhi weiyuanhui, 2005), 2.323 .

29 Itoh Masahiko 伊藤正彥, “'Chuantong shehui' xingcheng lun = 'jinshi hua' lun yu ‘Tang-Song biange' ‘傳統社會’形成論 = ‘近世化’ 論與 ‘唐宋變革” [The Theory of the Formation of 'Traditional Society' = the Theory of 'Modernization' and 'Tang-Song Transformation']," in Songshi yanjiu luncong 宋史研究論叢 [Series on Research in Song History], ed. Jiang Xidong 姜錫東 (Baoding: Hebei daxue chubanshe, 2013), 224-25. 
Most scholars, however, did not support Miyazaki's theory of the Song dynasty as the beginning of a European-style modernity in China.

In his book Le monde chinois, the well-known French sinologist Jacques Gernet called the Song dynasty the Chinese renaissance. ${ }^{30}$ The modernity that Gernet was talking about, however, was not the Song dynasty but the period between 1644 and 190o. For him, the Song dynasty was a pre-1644 bureaucratic dynasty.

In the United States, Song historians tended to see the transition from the Tang to the Song dynasty as the time when China moved from antiquity to modernity. By the 1970s, however, American historians of the Song basically negated the Japanese idea of a Tang-Song transformation. More recently, Western scholars have, instead, developed the paradigm of an "early modernity” [zaoqijindai 早期近代]. This type of research suggests that China's early modernity occurred simultaneously with the gradual commercialization of the late Ming dynasty, with commercialization considered a distinguishing characteristic of early modernity. ${ }^{31}$ Supporters of the early modernity paradigm were influenced by a Chinese theory developed in the 1940s, according to which China's sprouts of capitalism first appeared during the Ming dynasty.

\subsection{The Transformation Theory and Its Influence on Chinese Scholarship in the Twentieth Century}

Miyazaki Ichisada and others continued to develop Naitō Konan's work, and, by the end of World War II, Naitō's modernity theory had had long-lasting and wide-reaching influence on international Tang and Song studies. In China, by contrast, Naitō's hypothesis received little attention before the period of reform and opening up [1978]. This lack of academic interest prevented the modernity theory from having much influence on Tang and Song research in China. After the period of reform and opening up, the transformation theory eventually began to attract the attention of many Chinese historians. The effect on Chinese scholarship, however, remained limited throughout the 1980 os and 199os. The book Tang Studies in the Twentieth Century, published in 2002, for instance, has a comprehensive introduction to the Japanese discussion on the Tang-Song transformation as well as economic conditions during the Tang

30 Jacques Gernet 謝和耐, Zhongguo shehui shi 中國社會史 [History of Chinese Society], trans. Geng Sheng 耿昇 (Nanjing: Jiangsu renmin chubanshe, 1995). The original French title of Gernet's book is Le Monde Chinois. Cambridge University Press then published an English-language edition under the title $A$ History of Chinese Civilization.-Trans.

31 Endymion Wilkinson 魏根深, Zhongguo lishiyanjiu shouce 中國歷史研究手冊 [Chinese History: A Manual] (Beijing: Beijing daxue chubanshe, 2016), 1.2. 
dynasty. ${ }^{32}$ But it does not contain any references to mainland Chinese research on the transformation theory. The Catalogue of Writings on Song History in the Twentieth Century, published in 2006, equally lacks any entries for Chinese publications on the Tang-Song transformation. ${ }^{33}$

We conclude that the transformation theory represents only one of many Japanese schools of thought on Chinese historical periodization and on Tang and Song studies more generally. The theory neither represents a mainstream view in Japanese academia nor is widely accepted by international Song historians. In other words, only the Kyoto school has continuously propagated the modernity theory since the 1970s. International academic circles, including the Tokyo school, the Marxist school of historical materialism, and many in the new generation of scholars, have either abandoned or disproved the modernity theory.

Transformation Theory from a Critical Perspective

A search on the China National Knowledge Infrastructure $[\mathrm{CNKI}]^{34}$ yields nearly a thousand publications on Tang and Song history in the twenty-first century. More than two hundred results are returned from a search on keywords such as "transformation theory," "Naitō Konan," and "Miyazaki Ichisada," including master's theses and doctoral dissertations. ${ }^{35}$ Based on their general tenor, these publications can be divided into the following five groups.

The first group of publications is mainly introductory in nature, with representative works by Zhang Qifan 張其凡, Li Huarui 李華瑞, Zhang Guangda 張廣達, Liu Liyan 柳立言, Li Qing 李慶, Xiong Wei 熊偉, and others. ${ }^{36}$ Through

$32 \mathrm{Hu}$ Ji 胡戟, Zhang Gong 張弓, Ge Chengyong 葛承雍 and Li Bincheng 李斌城 eds., Ershi shiji Tang yanjiu二十世紀唐研究 [Tang Studies in the Twentieth Century] (Beijing: Zhongguo shehui kexue chubanshe, 2002).

33 Fang Jianxin 方建新, Ershi shiji Songshi yanjiu lunzhu mulu二十世紀宋史研究論著 目錄 [Catalogue of Writings on Song History in the Twentieth Century] (Beijing: Beijing tushuguan chubanshe, 2006).

34 The China National Knowledge Infrastructure [CNKI], or Zhongguo zhiwang 中國知網, is the most commonly used online site for Chinese academic content, including journals, conference proceedings, and dissertations; https://www.cnki.net (institutional access only).

35 Wang Qin 王秦, “Shinian lai ‘Tang-Song biange’ yanjiu shuping 十年來·唐宋變革’研究 述評 [Review of Research on the 'Tang-Song Transformation' over the Last Ten Years]," Changjiang shifan xueyuan xuebao 長江師範學院學報, no. 4 (2010).

36 Zhang Qifan 張其凡, “Guanyu 'Tang-Song biange qi' xueshuo de jieshao yu sikao 關 於 ‘唐宋變革期, 學說的介紹與思考 [Introduction and Thoughts on the Theory of a 
the continuous efforts of many, the majority of Chinese scholars researching the Tang and Song dynasties are now familiar with the basic paradigm and characteristics of the transformation theory. The level of familiarity and awareness of the theory's implications for China's historical periodization, however, vary among scholars.

The second group of publications is research focused and includes Qian Wanyue's 錢婉約 influential book Research on Naitō Konan [Neiteng Hunan yanjiu 內藤湖南研究] as well as a recent translation of Joshua Fogel's Politics and Sinology: The Case of Naitō Konan (1866-1934), which was first published more than thirty years ago. In addition to publications that provide a thorough analysis of the close connection between Naitō's political views and his academic work, there is also research that strongly approves of his modernity theory. Mou Fasong 牟發松, for instance, argues in his article "Three Questions about the Transformation Theory" that:

Naitō Konan not only had a comprehensive and systematic understanding of ancient Chinese culture, but visited China repeatedly for his research during the late Qing and early Republican period. Naitō believed that "the new Chinese culture that took shape during the Song dynasty has continued to exist until our modern age." This shows that Naitō's ideas were based on his profound understanding of both Chinese history as well as contemporary China, which had in turn a significant influence on him and the modernity theory. ${ }^{37}$

'Tang-Song Transformation Period']," Jinan xuebao (zhexue shehui kexue ban) 暨南學 報(哲學社會科學版), no. 1 (2001); Li Huarui 李華瑞, “20 shiji Zhong-Ri Tang-Song biange guan bijiao 20 世紀中日唐宋變革觀比較 [A Comparison of Chinese and Japanese Twentieth-Century Views on the Tang-Song Transformation]," Shixue lilun yanjiu 史學理論研究, no. 4 (2003); Zhang Guangda 張廣達, “Neiteng Hunan de Tang-Song biange shuo ji qi yingxiang 內藤湖南的唐宋變革說及其影響 [Naitō Konan's Tang-Song Transformation Theory and Its Influence]," Tang yanjiu 唐研究 11 (2005); Liu Liyan 柳立言, “He wei Tang-Song biange? 何謂唐宋變革? [What Is the Tang-Song Transformation?]," Zhonghua wenshi luncong 中華文史論叢, no. 1 (2006); Li Qing 李慶, “Guanyu Neiteng Hunan de Tang-Song biange lun 關於內藤湖南的唐宋變革論 [Naitō Konan's Tang-Song Transformation Theory]," Xueshu yuekan 學術月刊, no. 10 (2006); Xiong Wei, "Tang-Song biange lun tixi de yanhua."

37 Mou Fasong 牟發松, “'Tang-Song biange shuo' santi: Zhi cishuo chuangli yibai zhounian er zuo ‘唐宋變革說”三題——值此說創立一百周年而作 [Three Questions about 'The Tang-Song Transition': An Essay on the Occasion of Its Centennial Anniversary]," Huadong shifan daxue xuebao 華東師範大學學報, no. 1 (2010): 7; a more recent article is Mou Fasong 牟發松, “Wenhua jieshou shiye zhong de Tang-Song biange shulun 文 化接受視野中的唐宋變革述論 [The Transformation Theory from the Perspective of Cultural Acceptance]," Lishi jiaoxue wenti 歷史教學問題, no. 4 (2014): 66. 
The third group of publications analyzes the transition period between the Tang and the Song dynasty based on the transformation theory. The number of publications in this category, however, is relatively low. Of special interest is a series of articles on Song literature, intellectual history, and art history that support the use of the transformation theory as a guide for research in literature, intellectual history, and art history during the Song, Yuan, Ming, and Qing dynasties. Some of the more representative pieces in this group include Wang Shuizhao's 王水照 “Re-Evaluating the 'Naitō Proposition," in which he argues:

The re-evaluation of the "Naitō proposition" that we propose not only attempts to determine whether the "modernity theory" as such is correct or whether specific conclusions are in fact tenable, but seeks to further the academic development in our fields in general. A mature academic discipline not only relies on detailed descriptions and case-by-case analysis, but also requires a number of complete macro-narratives. This includes the need for a combined theoretical framework and the search for common regularities. ${ }^{38}$

Based on the idea of breaking down barriers between Tang and Song studies, the fourth group of publications discusses historical developments and changes in geography, transportation, culture, economy, and law under the framework of the transformation theory. In 2006, the Jianghan Tribune [Jianghan luntan 江漢論壇] published five articles under the common theme of Tang-Song transformation, with authors offering their views on the transformation period from the perspective of culture, military affairs, social hierarchy, and so on. ${ }^{39}$ Although the titles of many articles contain the term "Tang-Song

38 Wang Shuizhao 王水照, “Chongti 'Neiteng mingti' 重提‘內藤命題” [Re-Evaluating the 'Naitō Proposition']," Wenxue yichan 文學遺產, no. 2 (2006): 10-11.

39 Zhang Guogang 張國岡, “Lun Tang-Song biange de shidai tezheng 論唐宋變革的時代 特徵 [Discussing the Characteristics of the Tang-Song Transformation Era]," Jianghan luntan 江漢論壇, no. 3 (2006); Sun Jimin 孫繼民, "Tang-Song bingzhi bianhua yu Tang-Song shehui bianhua 唐宋兵制變化與唐宋社會變化 [Tang-Song Transformation in the Military System and in Society]," Jianghan luntan, no. 3 (2006); Li Tianshi 李天 石, “Zhonggu menfa zhidu de shuailuo yu Liangjian tixi de wajie 中古門閥制度的衰 落與良賤體系的瓦解 [The Decline of the Medieval System of Powerful Families and the Disintegration of the Liang-Jian System]," Jianghan luntan, no. 3 (2006); Du Wenyu 杜文玉, “Tang-Song shiqi shehui jieceng neibu jiegou de bianhua 唐宋時期社會階層 內部結構的變化 [The Changes of the Internal Structure of the Strata in Society during the Tang through Song Period]," Jianghan luntan, no. 3 (2006); Yan Yaozhong 嚴耀中, “Tang-Song biange zhong de daode zhishang qingxiang 唐宋變革中的道德至上傾向 [The Trend of Moralism in the Tang-Song Transition]," Jianghan luntan, no. 3 (2006). 
transformation," the articles mostly discuss the two dynasties individually or the period of transition between them. But they do not analyze the Tang-Song transformation as a Japanese theory of historical periodization.

The fifth group of publications treats the transformation theory as selfevident and speaks of a "societal transformation" whenever discussing questions concerning the Tang or Song dynasties. The meaning of the concept of societal transformation, however, remains broad and vague. ${ }^{40}$ This type of publications often do not directly concern the Tang-Song transformation as such. Instead, to support their own research conclusions, the authors often include the argument that the Tang and Song societies developed from an aristocracy into a society of common people and new elites.

A simple analysis of these five groups of publications demonstrates the following points. First, a continuing stream of introductory publications indicates sustained interest and enthusiasm for the transformation theory in the twenty-first century. Second, the sustained interest in the transformation theory has caused Chinese scholars, especially in Song literature, intellectual history, and art history, to place great importance on the enormous societal changes in the transition period between the two dynasties. They continuously analyze these changes in search of direction and a possible trajectory for the development of culture and thought after the Song. Third, scholars of Song literature, intellectual history, and art history support the use of the transformation theory as a guide in their fields. A closer analysis of their interpretation

40 See Gao Debu 高德步, “Tang-Song biange: Qimin dizhu jingji yu Qimin shehui de xingqi 唐宋變革: 齊民地主經濟與齊民社會的興起 [The Rise of the Landlord Economy and Society of the People of Qi]," Xueshu yanjiu 學術研究, no. 7 (2015); Li Jian 李健, “Tang-Song shiqi keji fazhan yu Tang-Song biange 唐宋時期科技發展與唐宋變革 [The Technological Advances in the Tang and Song Dynasties and the Connection with the Tang-Song Transformation]," Zhongzhou xuekan 中州學刊, no. 6 (2010); Tai Pengfei 邻鵬飛, “Tang-Song biange shiye xia de Tang Xizhou Shazhou de xiangcun zhidu yanbian 唐宋變革視野下的唐西州沙州的鄉村制度演變 [The Evolution of the Village System in Xizhou and Shazhou in the Tang Dynasty from the Perspective of the Tang-Song Transformation]," Xuchang xueyuan xuebao 許昌學院學報, no. 1 (2010); Sun Xiaodi 孫 小迪, “Jiyu Tang-Song biange lun de yinyue sixiang shi yanjiu fansi 基於唐宋變革論的 音樂思想史研究反思 [Reflections on the Research on the History of Musical Thought in View of the Tang-Song Transformation]," Dangdai yinyue 當代音樂, no. 24 (2016); Bi Weiming 畢嵬明, “'Tang-Song biange lun’ ji qi dui falü shi yanjiu de yiyi ‘唐宋變革論’ 及其對法律史研究的意義 ['The Tang-Song Transformation' and Its Meaning for the Research on Legal History]," Shanghai zhengfa xueyuan xuebao (fazhi luncong) 上海 政法學院學報 (法治論叢), no. 4 (2011); Zhang Kaixiang 張楷祥, “Tang-Song biange shijiao xia huihua yishu de shanbian 唐宋變革視角下繪畫藝術的嬗變 [The Evolution of the Art of Painting from the Perspective of the Tang-Song Transformation]," Meishu jiaoyuyanjiu 美術教育研究, no. 1 (2016). 
of the transformation theory shows that these theories are still highly regarded and widely propagated in their areas of research. At times, they tend to accept the theories uncritically. The use of the modernity theory, however, has shown few positive effects on research in intellectual history, Song literature, and art history because thse scholars mostly use the new theoretical framework to explain existing insights. Fourth, the fourth and fifth groups of publications show that the transformation theory has mostly served as a label in Tang and Song scholarship without really advancing or benefitting the field.

Transformation theory became a focus of academic discussion at the turn of the century for two reasons. The first reason is the ongoing process of reorientation in Song history. The second reason is that Chinese scholarship on the Song was based on theoretical paradigms from the 1950s and 196os that had not undergone any significant development since then. The upheavals in the Soviet Union and Eastern Europe in particular led to the marginalization of the Chinese historical periodization system based on ideas about historical materialism and the five social formations. This historical background enabled the transformation theory to become a focus of academic discussion at the turn of the twenty-first century.

If we look at the transformation theory from a critical perspective, few areas for further research remain. The Kyoto school has already fully developed the theoretical framework. All important questions have been discussed and proven in sufficient detail, leaving little room for further development. The main focus of the transformation theory has therefore shifted from the Song-Yuan transition period to the Ming-Qing transformation. This is why most Chinese scholars now focus on the final conclusions and not the reasoning behind the transformation theory.

In the twenty-first century, the transformation theory has had limited effects on Chinese Song studies. Since 200o, the Chinese community of Song historians has held a biannual competition for awards named after Deng Guangming 鄧廣銘 [1907-1998], with thirty-four winning publications (not including theses) to date. These publications are largely representative of the trends and standards in Song scholarship among established as well as upcoming Chinese scholars in the twenty-first century. However, none of the prize-winning publications were influenced by the transformation theory. Even publications that respond to the transformation theory do not rely on the theory in its discussion of historical changes during the Tang and Song dynasties. Rather, the authors find a way to distance themselves from this theoretical approach. The academic discourse in China's major journals and the topics at academic conferences in the field are formally still connected to the transformation theory. But almost all research presented under these themes actually analyzes 
major questions in Tang and Song history based on the assumption of continuity between the two dynasties. This type of research has little direct bearing on the transformation theory. Therefore, we can conclude that China's mainstream research on the Tang and Song dynasties has not been influenced by the transformation theory.

Over the past hundred years, the most influential theories and methods in Chinese and Japanese scholarship on Song history have been Western research methods in the social sciences and history. With regard to historical periodization, no consensus has been reached between the modernity theory and the theory of the decline of feudalist societies. To put it simply, the use of Western methods and theories leads to a different understanding of the nature of Song society. Apart from this difference, the areas of discussion and research are basically the same. ${ }^{41}$

By analyzing the modernity theory from six different perspectives, we demonstrate that scholars in Tang and Song studies should turn the page and leave the modernity theory (transformation theory) behind.

\section{Translated by Anja Bihler}

\section{Works Cited}

Bi Weiming 畢巍明. “Tang-Song biange lun’ ji qi dui falü shi yanjiu de yiyi ‘唐宋變革 論'及其對法律史研究的意義 ['The Tang-Song Transformation' and Its Meaning for the Research on Legal History]." Shanghai zhengfa xueyuan xuebao (fazhi luncong) 上海政法學院學報（法治論叢）, no. 4 (2011): 13-18.

Du Wenyu 杜文玉. “Tang-Song shiqi shehui jieceng neibu jiegou de bianhua 唐宋時期 社會階層內部結構的變化 [The Changes of the Internal Structure of the Strata in Society during the Tang and Song Period]." Jianghan luntan 江漢論壇, no. 3 (2006): 100-104.

Fang Jianxin 方建新. Ershi shiji Songshi yanjiu lunzhu mulu二十世紀宋史研究論著 目錄 [Catalogue of Writings on Song History during the Twentieth Century]. Beijing: Beijing tushuguan chubanshe, 2006.

Fogel, Joshua 傅佛果. Neiteng Hunan: Zhengzhi yu hanxue (1866-1934) 內藤湖南: 政 治與漢學(1866-1934) [Politics and Sinology: The Case of Naitō Konan (1866-1934)]. Translated by Tao Demin 陶德民 and He Yingying 何英䉆. Nanjing: Jiangsu renmin chubanshe, 2016.

41 See Yamane Yukio 山根幸夫, Zhongguo shiyanjiu rumen 中國史研究入門 [Introduction to the Study of Chinese History] (Beijing: Shehui kexue wenxian chubanshe, 2000), 504-89. 
Fu Sinian 傅斯年. Shixue fangfa daolun:Fu Sinian shixue wenji 史學方法導論: 傅斯年 史學文輯 [Introduction to Historical Methods: Collected Works on Historical Research by Fu Sinian]. Beijing: Zhongguo renmin daxue chubanshe, 2004.

Fukuzawa Yukichi 福澤諭吉. Bunmeiron no gairyaku 文明論之概略 [Outline of Civilization Theory]. Tokyo: Iwanami Shoten, 1931.

Gao Debu 高德步. “Tang-Song biange: Qimin dizhu jingji yu Qimin shehui de xingqi 唐 宋變革: 齊民地主經濟與齊民社會的興起 [The Rise of the Landlord Economy and Society of the People of Qi].” Xueshu yanjiu 學術研究, no. 7 (2015): 65-73.

Gernet, Jacques 謝和耐. Zhongguo shehui shi 中國社會史 [History of Chinese Society]. Translated by Geng Sheng 耿昇. Nanjing: Jiangsu renmin chubanshe, 1995.

Guizot, François. Histoire Générale de la Civilisation en Europe depuis la Chute de L'Empire Romain jusqu'à La Révolution Française. Brussels: N. J. Gregoir, V. Wouters et Cie, 1840.

Hou Jianxin 侯建新. “Xifang funü shi yanjiu shuping 西方婦女史研究述評 [Review of Western Research in Women's History].” Tianjin shifan daxue xuebao 天津師範大學 學報, no. 5 (1991): 52-57.

$\mathrm{Hu}$ Ji 胡戟, Zhang Gong 張弓, Ge Chengyong 葛承雍 and Li Bincheng 李斌城 eds., Ershi shiji Tang yanjiu 二十世紀唐研究 [Tang Studies during the Twentieth Century]. Beijing: Zhongguo shehui kexue chubanshe, 2002.

Itoh Masahiko 伊藤正彥. “'Chuantong shehui' xingcheng lun = 'jinshi hua' lun yu ‘Tang-Song biange’ ‘傳統社會'形成論 = ‘近世化’ 論與 ‘唐宋變革” [The Theory of the Formation of 'Traditional Society' = the Theory of 'Modernization' and 'Tang-Song Transformation']." In Songshi yanjiu luncong 宋史研究論叢 [Series on Research in Song History], edited by Jiang Xidong 姜錫東, 201-25. Baoding: Hebei daxue chubanshe, 2013 .

Kishimoto Mio 岸本美緒. “Congxin sikao zhongguo 'jinshi’ shi 從新思考中國“近世”史 [Rethinking 'Modernity' in Chinese History].” In Lishi fenluntan lunwen huo zhaiyao $j i$ 歷史分論壇論文或摘要集 [Collection of Conference Papers and Abstracts of the Forum on History], from the "Beijing Luntan (2005) Wenming de hexie yu gongtong fanrong 北京論壇 (2005) 文明的和諧與共同繁榮 [Beijing Forum 2005: The Harmony of Civilizations and Prosperity for All]," 2.323-42. Beijing: Beijing luntan zuzhi weiyuanhui, 2005 .

Li Huarui 李華瑞. “20 shiji Zhong-Ri Tang-Song biange guan bijiao 20 世紀中日唐宋變 革觀比較 [A Comparison of Chinese and Japanese Twentieth-Century Views on the Tang-Song Transformation]." Shixue lilun yanjiu 史學理論研究, no. 4 (2003): 87-95.

Li Jian 李健. “Tang-Song shiqi keji fazhan yu Tang-Song biange 唐宋時期科技發展與 唐宋變革 [The Technological Advances in the Tang and Song Dynasties and the Connection with the Tang-Song Transformation].” Zhongzhou xuekan 中州學刊, no. 6 (2010): 175-80. 
Li Qing 李慶. “Guanyu Neiteng Hunan de Tang-Song biange lun 關於內藤湖南的唐宋 變革論 [Naitō Konan's Tang-Song Transformation Theory].” Xueshu yuekan 學術月 刊, no. 10 (2006): 116-25.

Li Tianshi 李天石. “Zhonggu menfa zhidu de shuailuo yu liangjian tixi de wajie 中古門 閥制度的衰落與良賤體系的瓦解 [The Decline of the Medieval System of Powerful Families and the Disintegration of the Liang-Jian System]." Jianghan luntan 江漢論 壇, no. 3 (2006): 97-100.

Liu Liyan 柳立言. “He wei Tang-Song biange? 何謂唐宋變革? [What Is the Tang-Song Transformation?].” Zhonghua wenshi luncong 中華文史論叢, no. 1 (2006): 125-71.

Liu Yaochun 劉耀春. “Wenyi fuxing shiqi funü shi yanjiu 文藝復興時期婦女史研究 [Research on the History of Women during the Renaissance]." Lishi yanjiu 歷史 研究, no. 4 (2005): 176-87.

Miyazaki Ichisada 宮崎市定. “Dongyang de jinshi 東洋的近世 [East Asia's Early Modern Age].” In Riben xuezhe yanjiu Zhongguo shi lunzhu xuanyi 日本學者研究 中國史論著選譯 [Translations of Selected Works by Japanese Scholars on Chinese History], edited by Liu Junwen 劉俊文 and translated by Huang Yuese 黃約瑟, 1.153241. Beijing: Zhonghua shuju, 1992.

Mou Fasong 牟發松. “Wenhua jieshou shiye zhong de Tang-Song biange shulun 文化 接受視野中的唐宋變革述論 [The Transformation Theory from the Perspective of Cultural Acceptance]." Lishi jiaoxue wenti 歷史教學問題, no. 1 (2013): 8-16.

Mou Fasong 牟發松. “'Tang-Song biange shuo' santi: Zhi cishuo chuangli yibai zhounian er zuo ‘唐宋變革說”三題一值此說創立一百周年而作 [Three Questions about 'The Tang-Song Transition': An Essay on the Occasion of Its Centennial Anniversary].” Huadong shifan daxue xuebao 華東師範大學學報, no. 1 (2010): 1-10.

Naitō Konan 內藤湖南. “Gaikatsuteki Tō Sō jidai kan 概括的唐宋時代觀 [General View of the Tang and the Song].” Rekishi to chiri 歷史と地理 9, no. 5 (1922): 1-12.

Qian Wanyue 錢婉約. Neiteng Hunan yanjiu 內藤湖南研究 [Research on Naitō Konan]. Beijing: Zhonghua shuju, 2004.

Ren Seikichi 連清吉. “Neiteng Hunan yu Gongqi Shiding: Riben Jingdu Zhongguo xuezhe de shiguan 內藤湖南與宮崎市定一日本京都中國學者的史觀 [Naitō Konan and Miyazaki Ichisada: The Historical Viewpoint of the Sinologists of Japan's Tokyo School].” In Chang Bide jiaoshou bazhi jinwu shouqing lunwenji 昌彼得教授八秩晉 五壽慶論文集 [Festschrift for Professor Chang Bide's Eighty-Fifth Birthday], edited by Tamkang daxue zhongwenxi 淡江大學中文系 and Yu xian suo 語獻所, 325-44. Taipei: Taiwan xuesheng shuju, 2005.

Smith, Paul. “Song-Yuan-Ming de guodu wenti 宋、元、明的過渡問題 [The Question of the Song-Yuan-Ming Transition]." In Dangdaixifang hanxue yanjiu jicui: Zhonggushi juan 當代西方漢學研究集萃一中古史卷 [Selection of Research by Contemporary Western Sinologists: Ancient Chinese History], edited by Patricia Buckley Ebrey et al. 
and translated by Zhang Yi 張禕 et al., 247-86. Shanghai: Shanghai guji chubanshe, 2012.

Sugiyama Masaaki 杉山正明. Song-Yuan shixue de jiben wenti 宋元史學的基本問題 [Basic Questions of Song and Yuan History Studies]. Edited by Kondo Kazunari 近藤 一成. Beijing: Zhonghua shuju, 2010.

Sun Jimin 孫繼民. “Tang-Song bingzhi bianhua yu Tang-Song shehui bianhua 唐宋兵 制變化與唐宋社會變化 [Tang-Song Transformation in the Military System and in Society]." Jianghan luntan 江漢論壇, no. 3 (2006): 93-97.

Sun Xiaodi 孫小迪. “Jiyu Tang-Song biange lun de yinyue sixiang shi yanjiu fansi 基於 唐宋變革論的音樂思想史研究反思 [Reflections on the Research on the History of Musical Thought in View of the Tang-Song Transformation]." Dangdai yinyue 當代 音樂, no. 24 (2016): 10-13.

Tai Pengfei 郃鵬飛. “Tang-Song biange shiye xia de Tang Xizhou Shazhou de xiangcun zhidu yanbian 唐宋變革視野下的唐西州沙州的鄉村制度演變 [The Evolution of the Village System in Xizhou and Shazhou in the Tang Dynasty from the Perspective of the Tang-Song Transformation].” Xuchang xueyuan xuebao 許昌學院學報, no. 1 (2010): 90-94.

Wang Qin 王秦. “Shinian lai ‘Tang-Song biange’ yanjiu shuping 十年來‘唐宋變革’研 究述評 [Review of Research on the 'Tang-Song Transformation' over the Last Ten Years].” Changjiang shifan xueyuan xuebao 長江師範學院學報, no. 4 (2010): 38-43.

Wang Shuizhao 王水照. “Chongti 'Neiteng mingti' 重提“內藤命題” [Re-Evaluating the 'Naitō Proposition'].” Wenxue yichan 文學遺產, no. 2 (2006): 8-11.

Wang Suping 王素平. “Xifang xuejie guanyu jindai zaoqi Yingguo funü shi de yanjiu 西方學界關於近代早期英國婦女史的研究 [Western Academic Research on the Early Modern History of British Women]." Jingji shehui shi pinglun 經濟社會史評論, no. 3 (2010): 199-207.

Wilkinson, Endymion. Zhongguo lishi yanjiu shouce 中國歷史研究手冊 [Chinese History: A Manual], vol. 1. Beijing: Beijing daxue chubanshe, 2016.

Xiong Wei 熊偉. “Tang-Song biange lun tixi de yanhua 唐宋變革論體系的演化 [The Evolution of the System of the Tang-Song Transformation Theory]." Dianzi keji daxue xuebao 電子科技大學學報, no. 5 (2008): 92-96.

Yamane Yukio 山根幸夫. Zhongguo shi yanjiu rumen 中國史研究入門 [Introduction to the Study of Chinese History]. Beijing: Shehui kexue wenxian chubanshe, 2000.

Yan Yaozhong 嚴耀中. “Tang-Song biange zhong de daode zhishang qingxiang 唐宋 變革中的道德至上傾向 [The Trend of Moralism in the Tang-Song Transition].” Jianghan luntan 江漢論壇, no. 3 (2006): 104-6.

Yang Guo 楊果. “Xingbie shijiao xia de Songdai lishi 性別視角下的宋代歷史 [Song History from the Perspective of Gender]." Huaxia wenhua luntan 華夏文化論壇, no. 2 (2015): 16-24. 
Yang Yongliang 楊永亮. “Neiteng Hunan 'Songdai jinshi shuo' wenhua tanze 內藤 湖南“宋代近世說”文化探賾 [Exploring the Cultural Subtleties of Naitō Konan's 'Modernity Theory']." PhD diss., Northeast Normal University, 2015.

Zhang Guangda 張廣達. "Neiteng Hunan de Tang-Song biange shuo ji qi yingxiang 內 藤湖南的唐宋變革說及其影響 [Naitō Konan's Tang-Song Transformation Theory and Its Influence]." Tang yanjiu 唐研究 11 (2005): 5-72.

Zhang Guogang 張國剛. “Lun Tang-Song biange de shidai tezheng 論唐宋變革的時 代特徵 [Discussing the Characteristics of the Tang-Song Transformation Era]." Jianghan luntan 江漢論壇, no. 3 (2006): 89-93.

Zhang Kaixiang 張楷祥. “Tang-Song biange shijiao xia huihua yishu de shanbian 唐 宋變革視角下繪畫藝術的嬗變 [The Evolution of the Art of Painting from the Perspective of the Tang-Song Transformation]." Meishu jiaoyu yanjiu 美術教育研究, no. 1 (2016): 15-17.

Zhang Qifan 張其凡. “Guanyu 'Tang-Song biange qi' xueshuo de jieshao yu sikao 關 於 ‘唐宋變革期”學說的介紹與思考 [Introduction and Thoughts on the Theory of a 'Tang-Song Transformation Period']." Ji'nan xuebao (zhexue shehui kexue ban) 暨南 學報 (哲學社會科學版), no.1 (2001):124-31.

Zhejiang daxue Songxue yanjiu zhongxin 浙江大學宋學研究中心, ed. Songxue yanjiu jikan 宋學研究集刊 [Edited Volume of Research in Song Studies], vol. 1. Hangzhou: Zhejiang daxue chubanshe, 2008. 